\title{
SSR ANALYSIS OF SOME SYNONYMS AND HOMONYMS OF GRAPE CULTIVARS (VITIS VINIFERA L.) GROWING IN SOUTHEASTERN TURKEY
}

\author{
KARATAȘ, H. \\ Dicle University, Agriculture Faculty, Horticulture Department, 21280 Diyarbakır, Turkey \\ (e-mail: hkaratas@dicle.edu.tr; phone: +90-412-248-8509) \\ (Received 26 $6^{\text {th }}$ Mar 2019; accepted $13^{\text {th }}$ Jun 2019)
}

\begin{abstract}
The goal of this study was to analyze the genetic diversity of grape cultivars growing in Diyarbakır and Şanlıurfa by performing SSR molecular identification of the synonymous and homonymous genotypes of 21 cultivars growing in these two regions to investigate the homonyms (Vitis vinifera L. cvs.). Microsatellite analysis was performed using a minimal standard SSR marker set involving 7 highly polymorphic loci (VVS2, VVMD5, VVMD7, VVMD27, VrZAG47, VrZAG62, and VrZAG62). Mean number of alleles per locus was 7.14 (range, 7-9), with the highest number of alleles detected in VVS2 and the lowest in VVMD7, VVMD27. The expected and observed heterozygosity were 0.70 and 0.69 , respectively. The dendrogram indicated 3 distinct groups, each of which involved several subgroups. A total of 5 synonyms and 10 homonyms were identified for the 21 genotypes.
\end{abstract}

Keywords: Vitis vinifera L., grape cultivars, DNA extraction, synonym, homonym, dendrogram

\section{Introduction}

Diyarbakır and Şanlıurfa provinces are located in Southeastern Turkey where viticulture is widely performed. Grapevine is a well-known perennial garden plant well adapted to these regions. Some preliminary surveys and genomic studies have revealed more than 70 grape cultivars growing in these two regions. Moreover, these two regions not only are well-known for viticulture but also are among the regions with the highest grape production in Turkey. Nevertheless, there is little or no information regarding the exact cultivar-based vineyard capacity of these regions.

The use of different regional names for grape cultivars results in major problems and confusion regarding the correspondence between these names and those used in studies and those used in each phase of production. However, these problems and confusion can be eliminated by the administration of molecular markers of polymorphism.

The aim of this study was to analyze the genetic diversity of grape cultivars growing in Diyarbakır and Şanlıurfa by performing molecular identification of the genotypes of cultivars growing in these two regions and to investigate the homonyms used for the 21 distinct cultivars (Vitis vinifera L. cvs.) previously identified in these regions using the SSR technique. Simple Sequence Repeats (SSR) is a well-known molecular marker which has been commonly used for the identification of cultivars and the determination of synonyms and homonyms of grape genotypes (Thomas and Scott, 1993; Bowers et al., 1996; Meredith et al., 1996; Sefc et al., 1997, 1999; Meredith, 2001; Riaz et al., 2002; Fatahi et al., 2003; Grando et al., 2003; Hvarleva et al., 2004; Riaz et al., 2004; AdamBlondon et al., 2004; Zulini et al., 2005; Costantini et al., 2005; Di Vecchi Staraz et al., 2006, 2009; Şelli et al., 2007; Bodor et al., 2010; Cipriani et al., 2010; Ocete et al., 2011; De Andres et al., 2011; Garcia-Munoz et al., 2012; Emanuelli et al., 2013; Alifragkis et al., 2015; Maletic et al., 2015; Biagini et al., 2016; Li et al., 2017; Zequim Maia et al., 2018; Van Heerden et al., 2018). 


\section{Materials}

Molecular analysis was conducted on 21 grapevine genotypes including 9 cultivars collected from Diyarbakir Province and its districts (D), 8 cultivars collected from Şanlıurfa Province and its districts (Ş) and 4 genotype samples of the cultivars that had been previously transplanted to the Tekirdağ National Germplasm Repository Vineyard (TD, TŞ) (Figure 1).

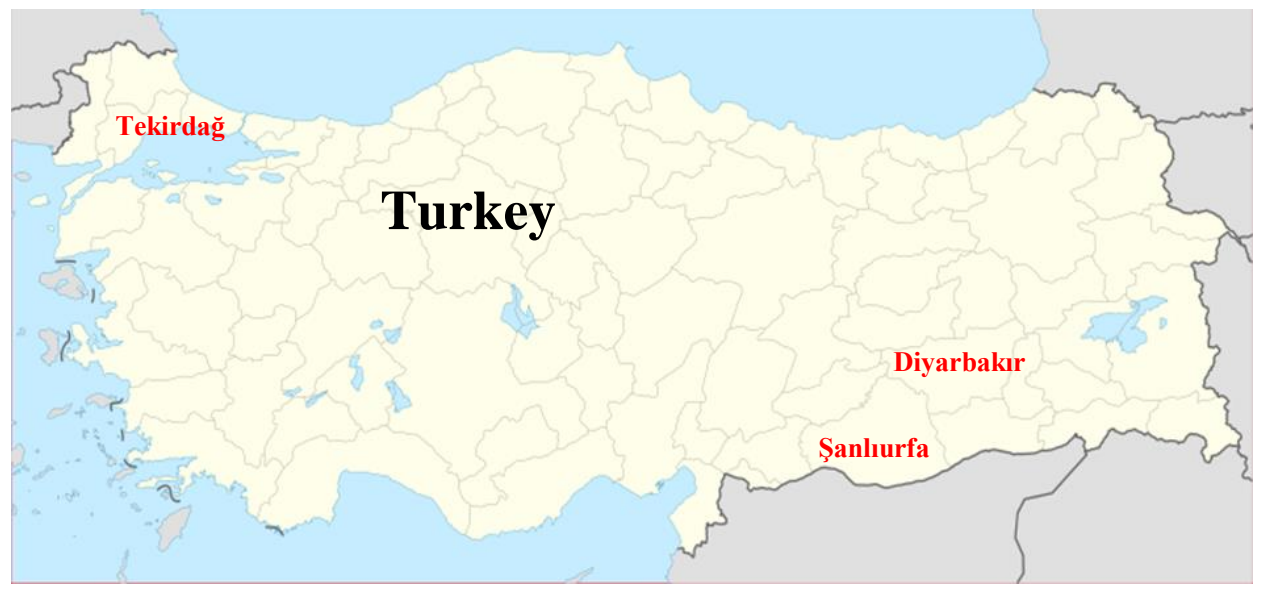

Figure 1. Provinces where the grapevine genotypes collected from Turkey

One-year-old seedlings with 3-5 buds were collected from each genotype and were planted in polyethylene tubes filled with a 2:2:1 mixture of perlite, turf, and powder and then germinated in greenhouse conditions until the buds were rooted. DNA extraction was performed with the fresh leaves of these buds, as described by (Lodhi et al., 1994).

\section{Methods}

In order to allow a comparison among internationally grown homonymous varieties, a minimal standard SSR marker set was employed (This et al., 2004), which includes 7 highly polymorphic loci as follows: VVS2, VVMD5, VVMD7, VVMD27, VrZAG47, VrZAG62, VrZAG79 (Table 1).

DNA amplification was carried out using GeneAmp PCR System 9700 with EUApplied Biossystems, followed by PCR optimization for each cultivar. PCR amplification was achieved using a reaction volume of $20 \mu \mathrm{l}$ containing $5 \mu \mathrm{l}$ of DNA (10 ng/ $\mu \mathrm{l}), 2 \mu \mathrm{l}$ of 10X Buffer (Qiagen), $1.2 \mu \mathrm{l}$ of $\mathrm{Mg} \mathrm{Cl} 2$ (Qiagen), $0.6 \mu 1$ of dNTP (10mM), $1 \mu 1$ of primer $(25 \mu \mathrm{M}) 1,1 \mu 1$ of primer $2(25 \mu \mathrm{M}), 0.2 \mu 1$ of GoldTaq $(0.5 \mathrm{U})$, and 9 of $\mu 1$ distilled water. Touchdown PCR was carried out using the following cycling conditions: $95^{\circ} \mathrm{C}$ for $10 \mathrm{~min}, 94^{\circ} \mathrm{C}$ for $30 \mathrm{~s}$, and $52^{\circ} \mathrm{C}$ for VVS2, VVMD5, and VVMD7, $58^{\circ} \mathrm{C}$ for VVMD27, $55^{\circ} \mathrm{C}$ for VrZAG47, and $62^{\circ} \mathrm{C}$ for VrZAG62 and VrZAG79 for $30 \mathrm{~s}$ each, based on the rate of primer annealing, with a decrease of $0.2^{\circ} \mathrm{C} /$ cycle. After completing 25 cycles, additional 15 cycles were administered with a reduction of $5^{\circ} \mathrm{C}$ from the primer annealing temperature, finally followed by holding at $72^{\circ} \mathrm{C}$ for $40 \mathrm{~min}$.

To understand whether amplification occurs for each fragment in each locus, at least 10 fragments typifying each locus were placed on agarose gel. After viewing the amplification, the amplified fragments were subjected to sequencing using ABI Prism 
3730 automated DNA sequencer with GeneScan ${ }^{\mathrm{TM}} 500$ LIZ $^{\mathrm{TM}}$ dye Size Standard. The outcomes were analyzed, visualized, and processed using GeneMapper v 3.7 software. The number of alleles in each locus was calculated based on the peak levels.

Table 1. Primers used for the study

\begin{tabular}{|c|c|c|c|c|}
\hline Primer & $5^{\prime}-3^{\prime}$ & Base sequences of primers & & Reference \\
\hline \multirow{2}{*}{ VVS2 } & $\mathrm{F}$ & VIC-CAG CCC GTA AAT GTA TCC ATC & Vic & \multirow{2}{*}{$\begin{array}{c}\text { Thomas and Scott } \\
\text { (1993) }\end{array}$} \\
\hline & $\mathrm{R}$ & AAA TTC AAA ATT CTA ATT CAA CTG G & & \\
\hline \multirow{2}{*}{ VVMD5 } & $\mathrm{F}$ & 6-FAM-CTA GAG CTA CGC CAA TCC AA & Fam & \multirow{6}{*}{$\begin{array}{c}\text { Bowers et al. (1996, } \\
\text { 1999) }\end{array}$} \\
\hline & $\mathrm{R}$ & TAT ACC AAA AAT CAT ATT CCT AAA & & \\
\hline \multirow{2}{*}{ VVMD7 } & $\mathrm{F}$ & NED-AGA GTT GCG GAG AAC AGG AT & Ned & \\
\hline & $\mathrm{R}$ & CGA ACC TTC ACA CGC TTG AT & & \\
\hline \multirow{2}{*}{ VVMD27 } & $\mathrm{F}$ & NED-GTA CCA GAT CTG AAT ACA TCC GTA AGT & Ned & \\
\hline & $\mathrm{R}$ & ACG GGT ATA GAG CAA ACG GTG T & & \\
\hline \multirow{2}{*}{ VrZAG47 } & F & VIC-GGTCTGAATACATCCGTAAGTATAT & Vic & \multirow{6}{*}{ Sefc et al. (1999) } \\
\hline & $\mathrm{R}$ & ACGGTGTGCTCTCATTGTCATTGAC & & \\
\hline \multirow{2}{*}{ VrZAG62 } & $\mathrm{F}$ & 6-FAM-GGT GAA ATG GGC ACC GAA CAC ACG C & Fam & \\
\hline & $\mathrm{R}$ & CCA TGT CTC TCC TCA GCT TCT CAG C & & \\
\hline \multirow{2}{*}{ VrZAG79 } & $\mathrm{F}$ & 6-FAM-AGA TTG TGG AGG AGG GAA CAA ACC G & Fam & \\
\hline & $\mathrm{R}$ & TGC CCC CAT TTT CAA ACT CCC TTC C & & \\
\hline
\end{tabular}

Genetic similarity between the 21 genotype samples characterized by 7 loci was analyzing using the Microsat software (Minch et al., 1995) and the genetic parameters (number of alleles per locus, allele frequency, expected heterozygosity, observed heterozygosity, parentage, null allele frequency, and probability of identity) were analyzed using the IDENTITY 1.0 software (Wagner and Sefc, 1999). The dendrograms were formed and viewed using the NTSys software (version 2.02g, Exeter Software, Setauket, NY). Clustering analysis was carried out using the UPGMA method (Unweighted Pair-Group Method using Arithmetic means).

\section{Result and Discussion}

Data regarding the molecular analysis of the 21 genotype samples characterized by 7 loci were presented in Table 2 in the form of peak levels and the number of alleles and basepair per locus.

The SSR analysis indicated a total of 50 alleles for the 21 genotype samples obtained from Diyarbakır, Şanlıurfa, and the Tekirdağ National Germplasm Repository Vineyard. Table 3 presents the number of alleles and the expected and observed heterozygosity for these genotypes. Mean number of alleles per locus was 7.14, which was reported to be 9.6, by Borrego et al. (2001) who analyzed 406 accessions characterized by 8 microsatellite markers, 11.4 by Fatahi et al. (2003) who analyzed 62 genotypes characterized by 9 microsatellite markers, 8.1 by Hvarleva et al. (2004) who analyzed 74 accessions characterized by 9 microsatellite markers, 9.1 by Akkak et al. (2005) who analyzed 60 local cultivars characterized by 12 microsatellite markers, 11.9 by Vouillamoz et al. (2006), who analyzed 116 accessions characterized by 12 microsatellite markers. Of these studies, the ones that identified higher mean numbers of alleles compared to that of our study were carried out with higher numbers of genotypes that also showed greater variation compared to those in our study. However, the studies conducted by Crespan and Milani (2001), Dangl et al. (2001), Hvarleva et al. (2004) and Costantini 
et al. (2005) were carried out with lower numbers of genotypes and therefore detected lower mean numbers of alleles compared to that of our study (Table 3). On the contrary, although Fatahi et al. (2003) and Akkak et al. (2005) analyzed a smaller variety of genotype samples, the two studies identified greater mean numbers of alleles compared to that of our study.

Table 2. Allele sizes of the genotypes characterized by 7 microsatellite loci

\begin{tabular}{|c|c|c|c|c|c|c|c|c|c|c|c|c|c|c|}
\hline No & Genotype & \multicolumn{2}{|c|}{ VVS2 } & VVMD5 & \multicolumn{2}{|c|}{ VVMD7 } & \multicolumn{2}{|c|}{ VVMD27 } & \multicolumn{2}{|c|}{ VrZAG47 } & \multicolumn{2}{|c|}{ VrZAG62 } & \multicolumn{2}{|c|}{ VrZAG79 } \\
\hline 1 & D Abderi & 131 & 133 & $230 \quad 232$ & 240 & 244 & 181 & 181 & 159 & 159 & 186 & 190 & 246 & 246 \\
\hline 2 & TDAbderi & 131 & 133 & $230 \quad 232$ & 240 & 244 & 181 & 181 & 159 & 159 & 186 & 190 & 246 & 246 \\
\hline 3 & Ş Avderi & 139 & 149 & $228 \quad 234$ & 244 & 244 & 191 & 191 & 169 & 169 & 190 & 202 & 254 & 254 \\
\hline 4 & $D$ Hatunparmağ beyaz & 139 & 143 & $232 \quad 242$ & 236 & 244 & 191 & 191 & 169 & 169 & 186 & 202 & 244 & 248 \\
\hline 5 & $D$ Hatunparmağı siyah & 121 & 121 & $232 \quad 242$ & 236 & 252 & 185 & 191 & 163 & 169 & 202 & 202 & 244 & 246 \\
\hline 6 & Ş Hatunparmağı siyah & 131 & 149 & $230 \quad 232$ & 230 & 244 & 191 & 191 & 169 & 169 & 194 & 202 & 244 & 254 \\
\hline 7 & $S ̧$ Hatunparmağ beyaz & 131 & 133 & $222 \quad 230$ & 244 & 246 & 191 & 191 & 169 & 169 & 190 & 202 & 240 & 248 \\
\hline 8 & D Kızılbanki & 131 & 141 & 232236 & 240 & 246 & 181 & 191 & 159 & 169 & 188 & 188 & 244 & 246 \\
\hline 9 & & 131 & 141 & $222 \quad 232$ & 240 & & 181 & 191 & 159 & 169 & 188 & 188 & 244 & 254 \\
\hline 10 & $D$ Şire mazrumi & 131 & 131 & $232 \quad 232$ & 244 & & & 191 & 155 & 169 & 198 & 202 & & 246 \\
\hline 11 & $D$ Şire şirelik & 131 & & $232 \quad 232$ & 244 & & 177 & 191 & 155 & 169 & 198 & 202 & & 244 \\
\hline 12 & & 133 & 139 & $222 \quad 234$ & 244 & & 177 & 191 & 155 & 169 & 194 & 198 & 246 & 256 \\
\hline 13 & $D$ Tahannebi & 131 & 131 & $232 \quad 232$ & 244 & & 177 & 191 & 155 & 169 & 198 & 202 & 244 & 246 \\
\hline 14 & $T D$ Tahannebi & 131 & 155 & $230 \quad 234$ & 244 & 244 & 191 & 191 & 169 & 169 & 190 & 202 & 254 & 254 \\
\hline 15 & Ş Tahannebi & 131 & 155 & $230 \quad 234$ & 244 & 244 & 191 & 191 & 169 & 169 & 190 & 202 & 254 & 254 \\
\hline 16 & $T D$ Siyahüzüm & 133 & 155 & $222 \quad 232$ & 244 & 246 & 181 & 191 & 159 & 169 & 190 & 198 & 244 & 246 \\
\hline 17 & Ş Siyahüzüm & 133 & 139 & $222 \quad 234$ & 244 & 246 & 191 & 191 & 155 & 169 & 194 & 198 & 246 & 246 \\
\hline 18 & $D$ Şarabi & 149 & 155 & $232 \quad 234$ & 244 & 246 & 183 & 191 & 161 & 169 & 190 & 198 & 248 & 256 \\
\hline 19 & Ş Şarabi & 141 & 149 & $230 \quad 242$ & 230 & 246 & 175 & 191 & 153 & 169 & 202 & 202 & 240 & 244 \\
\hline 20 & $D$ Zerik & 133 & 153 & $230 \quad 232$ & 244 & 244 & 191 & 191 & 157 & 169 & 190 & 198 & 248 & 254 \\
\hline 21 & $T S S$ Zerik & 131 & 143 & $228 \quad 228$ & 244 & 246 & 191 & 191 & 155 & 155 & 190 & 202 & 246 & 248 \\
\hline
\end{tabular}

D: Diyarbakır Province; T: Tekirdag Province (National Germplasm Repository Vineyard); SS: Sanlıurfa Province; TD: Tekirdag National Germplasm Repository (studied cultivars from Diyarbakır); TŞ: National Germplasm Repository (studied cultivars from Sanliurfa)

Microsatellite markers used in our study, the most polymorphic marker was VVS2 (9 alleles) and the lowest were VVMD7 and VVMD27 (7 alleles) (Table 3). Similarly, previous studies also indicated that VVS2 the most polymorphic marker, followed by VVMD5 and VVMD27 (9 alleles), and VVMD7, VrZAG62, and VrZAG79 (7 alleles) (López et al., 1999; Borrego et al., 2001; Lefort and Roubelakis-Angelakis, 2001; Fatahi et al., 2003; Martín et al., 2003; Núñez et al., 2004). In our study, the expected heterozygosity per locus ranged from 0.47 and 0.80 , with lowest expected heterozygosity detected in VVMD27 and the highest in VVS2. However, no significant difference was found between these two values, implicating that the cultivars analyzed in our study were highly heterozygous. In contrast, the observed heterozygosity detected in our study was lower than those reported in the literature (Sefc et al., 2000; Dangl et al., 2001; Fatahi et al., 2003; Aradhya et al., 2003; Costantini et al., 2005; Vouillamoz et al., 2006).

Clustering analysis was performed based on the proportion of shared alleles between the cultivars collected from Diyarbakır and Şanlıurfa. The dendrogram indicated 3 
distinct groups, each of which involved several subgroups. The dendrogram demonstrated that the genotypes of the cultivars obtained from these two regions were not completely dissimilar but showed close relationship with each other (Figure 2).

Table 3. Number of alleles per locus, He, Ho, and PI

\begin{tabular}{c|c|c|c|c}
\hline Marker & Number of alleles & He & Ho & PI \\
\hline VVS2 & 9 & 0.80 & 0.82 & 0.78 \\
VVMD5 & 7 & 0.78 & 0.82 & 0.75 \\
VVMD7 & 6 & 0.64 & 0.82 & 0.59 \\
VVMD27 & 6 & 0.47 & 0.41 & 0.44 \\
VrZAG47 & 8 & 0.65 & 0.55 & 0.61 \\
VrZAG62 & 7 & 0.79 & 0.77 & 0.77 \\
VrZAG79 & 7 & 0.79 & 0.64 & 0.76 \\
\hline Mean & $\mathbf{7 . 1 4}$ & $\mathbf{0 . 7 0}$ & $\mathbf{0 . 6 9}$ & $\mathbf{0 . 6 7}$ \\
\hline
\end{tabular}

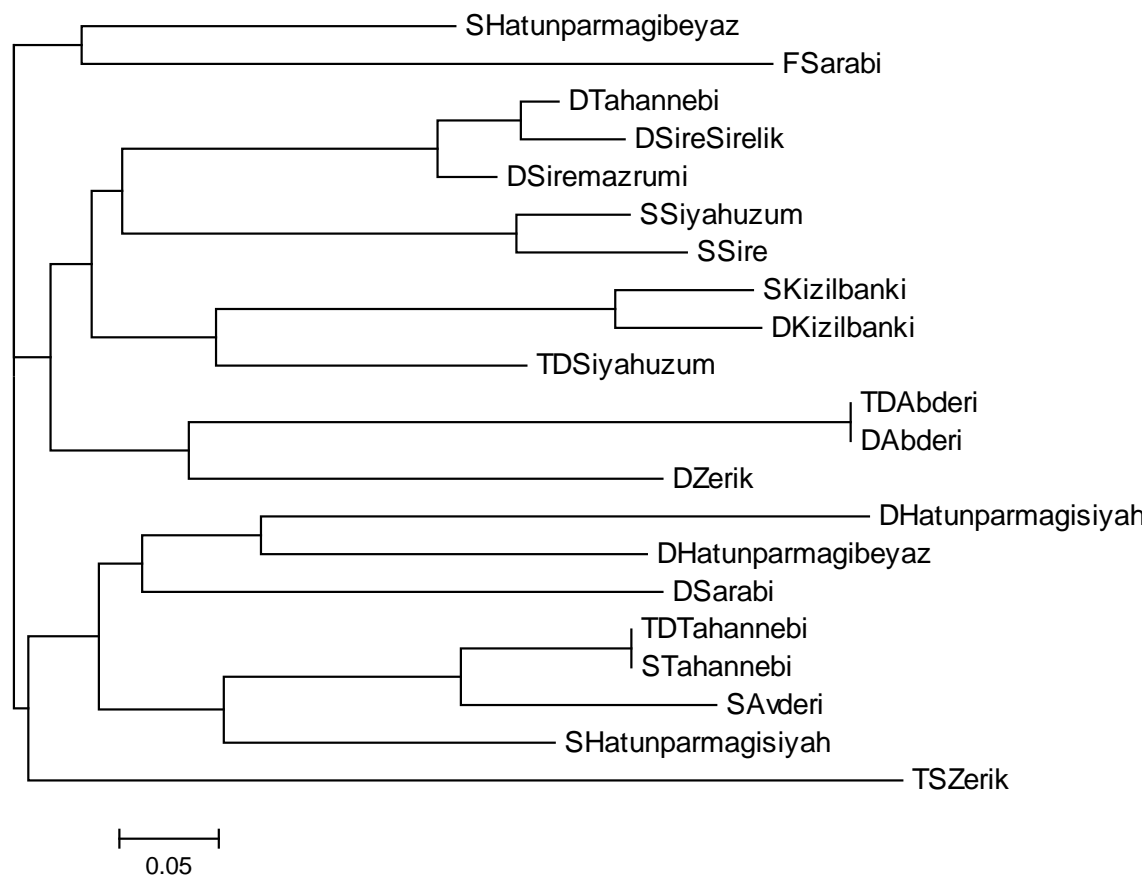

Figure 2. Dendogram of 21 grape cultivars (Diyarbakır-Şanlurfa) based on similarity index from SSR data

The dendrogram indicated that only 6 out of the 17 cultivars sampled from Diyarbakır and Şanlıurfa were classified as homonyms or as cultivars with highly similar names (i.e. clustered in the same group on the dendrogram). However, 2 out of the 4 cultivars sampled from the Tekirdağ National Germplasm Repository Vineyard were found to have dissimilar names (i.e. not clustered in the same group on the dendrogram). The dendrogram also revealed that some of the cultivars with the same name were genetically not identical, which suggests that some of the grape cultivars growing in these regions might develop different genetic traits over time due to the different ecological conditions they grow in. Accordingly, the overwhelming presence of homonyms used for grape 
genotypes is a major problem for the viticulture in Turkey. The extent of this problem is well elucidated in the present study.

The molecular analysis indicated that 5 synonyms and 10 homonyms were identified for the 21 genotypes analyzed with 7 microsatellite markers based on the proportion of shared alleles among the genotypes (Table 3). Nevertheless, no clear information was available as to which homonym represented the real name of each genotype.

Table 4. Synonyms and homonyms identified for the genotype samples obtained from Diyarbakır and Şanlıurfa

\begin{tabular}{|l|}
\hline Synonyms \\
\hline$D$ Tahannebi, $D$ Şire şirelik \\
Ş Siyahüzüm, $S$ Şire \\
$D$ Hatunparmağı siyah, $D$ Hatunparmağı beyaz \\
\hline Homonyms \\
\hline Ş Hatunparmağı beyaz, Ş Hatunparmağı beyaz ( $D$ Hatunparmağı siyah- $D$ Hatunparmağı beyaz) \\
$D$ Şire mazrumi, $S$ Şire, $D$ Şire şirelik \\
$S$ Avderi ( $D$ Abderi- $T D$ Abderi) \\
$D$ Tahannebi $(T D$ Tahannebi-Ş Tahannebi) \\
$D$ Şarabi, $S$ Şarabi \\
$T D$ Siyahüzüm, SS Siyahüzüm \\
$D$ Zerik, $T S ̧$ Zerik \\
\hline
\end{tabular}

The microsatellite analysis revealed a total of 13 distinct cultivars for the 21 genotype samples. This finding implicates that the gene sources of the cultivars growing in these two regions should be protected. Moreover, it was also revealed that the 7 loci used in our study were highly appropriate for genetic analysis of grape cultivars and the identification of synonyms and homonyms.

\section{Conclusion}

A high level of allelic polymorphism was found between the cultivars that were expected to have dissimilar names and between the cultivars that were expected to have similar names. In our study it was observed that the level of detected polymorphism is highly can be influenced by the source materials. This differentiation of nomenclature could be attributed to several conditions. First, the cultivars with the same names might have been initially genetically identical but later grown in different ecological conditions for long years and thus might have become genetically dissimilar and this differentiation might have been further intensified through the use of different names for the cultivars transplanted to the Tekirdağ National Germplasm Repository Vineyard. Secondly, this differentiation could be associated with the production of these cultivars for constant vegetative propagation and the somatic mutations induced by environmental factors. Turkey is home to numerous grape cultivars with the same or different names as a result of a long-standing viticulture tradition in Anatolia dating back to 7,000-8,000 years ago. To protect this genetic potential, devising a rational nomenclature and identifying the relationships among these cultivars by using DNA-based markers is highly essential. 


\section{REFERENCES}

[1] Adam-Blondon, A. F., Roux, C., Claux, D., Butterlin, G., Merdinoglu, D., This, P. (2004): Mapping 245 SSR markers on the Vitis vinifera genome: a tool for grape genetics. Theoretical and Applied Genetics 109(5): 1017-1027.

[2] Akkak, A., Boccacci, P., Lacombe, T., Botta, R. (2005): Relationships and genetic diversity of grapevine (Vitis vinifera L.) grown in Algeria and in Mediterranean basin. - Electronic Forum on Biotechnology in Food and Agriculture, Conference 13. International Workshop, 5- March 2005, Turin, Italy. (Poster).

[3] Alifragkis, A., Cunha. J., Pereira. J., Fevereiro, P., Eiras Dias, J. (2015): Identity, synonymies and homonymies of minor grapevine cultivars maintained in the Portuguese ampelographic collection. - Ciência Téc Vitic 30: 43-52.

[4] Aradhya, M. K., Dangl, G. S., Prins, B. H., Boursiquot, J. M., Walker, M. A., Meredith, C. P., Simon, C. J. (2003): Genetic structure and differentiation in cultivated grape, Vitis vinifera L. - Genet. Res. Camb. 81: 179-192.

[5] Biagini, B., Imazio, S., Scienza, A., Failla, O., De Lorenzis, G. (2016): Renewal of wild grapevine (Vitis vinifera L. subsp. sylvestris (Gmelin) Hegi) populations through sexual pathway: Some Italian case studies. - Flora 219: 85-93.

[6] Bodor, P., Höhn, M., Pedryc, A., Deák, T., Dücső, I., Uzun, I., Cseke, K., Böhm, É. I., Bisztray, G. D. (2010): Conservation value of the native Hungarian wild grape (Vitis silvestris Gmel.) evaluated by microsatellite markers. - Vitis 49(1): 23-27.

[7] Borrego, J., Rodriguez, I., Andrés, M. T., Martin, J., Chavez, J., Cabello, F., Ibáñez, J. (2001): Characterization of the most important Spanish grape varieties through isoenzyme and microsatellite analysis. - Proc. Int. Symp. on Molecular Markers. Acta Hort. 546: 371375 .

[8] Bowers, J. E., Dangl, G. S., Vignani, R., Meredith, C. P. (1996): Isolation and characterization of new polymorphic simple sequence repeat loci in grape (Vitis vinifera L.). - Genome 39: 628-633.

[9] Bowers, J. E., Dangl, G. S., Meredith, C. P. (1999): Development and characterization of additional microsatellite DNA markers for grape. - Am. J. Enol. Vitic. 50(3): 243-246.

[10] Cipriani, G., Spadotto, A., Jurman, I., Di Gaspero, G., Crespan, M., Meneghetti, S., Frare, E., Vignani, R., Cresti, M., Morgante, M., Pezzotti, M., Pe, E., Policriti, A., Testolin, R. (2010): The SSR-based molecular profile of 1005 grapevine (Vitis vinifera L.) accessions uncovers new synonymy and parentages, and reveals a large admixture amongst varieties of different geographic origin. - Theor Appl Genet 121: 1569-1585.

[11] Costantini, L., Monaco, A., Vouillamoz, J. F., Forlani, M., Grando, M. S. (2005): Genetic relationships among local Vitis vinifera cultivars from Campania (Italy). - Vitis 44(1): 2534.

[12] Crespan, M., Milani, N. (2001): The Muscats: A molecular analysis of synonyms, homonyms and genetic relationship within a large family of grapevine cultivars. - Vitis 40(1): 23-30.

[13] Dangl, G. S., Mendum, M. L., Prins, B. H., Walker, A. M., Meredith, C. P., Simon, C. J. (2001): Simple sequence repeat analysis of a clonally propagated species: A tool for managing a grape germplasm collection. - Genome 44: 432-438.

[14] De Andrés, M. T., Benito, A., Pérez-Rivera, G. (2012): Genetic diversity of wild grapevine populations in Spain and their genetic relationships with cultivated grapevines. - Molecular Ecology 21: 800-816.

[15] Di-Vecchi Staraz, M., Laucou, V., Bruno, G., Lacombe, T., Gerber, S., Bourse,T., Boselli, M., This, P. (2009): Low Level of Polen-Mediated Gene Flow from Cultivated to Wild Grapevine: Consequences fort he Evolution of the Endangered Subspecies Vitis vinifera L. subsp. silvestris. - Journal of Heredity 100(1): 66-75.

[16] Emanuelli, F., Lorenzi, S., Grzeskowiak, L., Catalano, V., Stefanini, M., Troggio, M., Myles, S., Martinez-Zapater, J. M., Zyprian, E., Moreira, F. M., Grando, M. S. (2013): 
Genetic diversity and population structure assessed by SSR and SNP markers in a large germplasm collection of grape. - BMC Plant Biol. 13: 39. DOI: 10.1186/1471-2229-1339.

[17] Fatahi, R., Ebadi, A., Bassil, N., Mehlenbacher, S. A., Zamani, Z. (2003): Characterization of Iranian grapevine cultivars using microsatellite markers. - Vitis 42(4): 185-192.

[18] Grando, M. S., Bellin, D., Edwards, K. J., Pozzi, C., Stefanini, M., Velasco, R. (2003): Molecular linkage maps of Vitis vinifera L. and Vitis riparia Mchx. - Theoretical and applied genetics 106(7): 1213-1224.

[19] Hvarleva, T., Rusanov, K., Lefort, F., Tsvetkov, I., Atanassov, A., Atanassov, I. (2004): Genotyping of Bulgarian Vitis vinifera L. cultivars by microsatellite analysis. - Vitis 43(1): 27-34.

[20] Lefort, F., Roubelakis-Angelakis, K. A. (2001): Genetic comparison of Greek cultivars of Vitis vinifera L. by nuclear microsatellite profiling. - American Journal of Enology\&Viticulture 52(2): 101-108.

[21] Li, B., Jianfu, J., Xiucai, F., Ying, Z., Haisheng, S., Guohai, Z., Chonghuai, L. (2017): Molecular characterization of Chinese grape landraces (Vitis L.) using microsatellite DNA markers. - Hort Science 52: 533-540.

[22] Lodhi, M. A., Daly, M. J., Ye, G. N., Weeden, N. F., Reisch, B. I. (1994): A simple and efficient method for DNA extraction from grapevine cultivars and Vitis species. - Plant Mol. Biol. 12(1): 6-13.

[23] Lópes, M. S., Sefc, K. M., Dias, E. E., Steinkellner, H., Machado, M. L. D., Machado, A. D. (1999): The use of microsatellites for germplasm management in a Portuguese grapevine collection. - Theor. Appl. Genet. 99(3-4): 733-739.

[24] Maletıć, E., Pejıć, I., Karogla Kontıć, J., Zdunıć, G., Preıner, D., Simon, S., Andabaka, Z., ZuljMihaljevic, M., Bubola, M., Markovic, Z., Stupic, D., Mucalo, A. (2015): Ampelographic and genetic characterization of Croatian grapevine varieties. - Vitis 54(Special Issue): 93-98.

[25] Martin, J. P., Borrego, J., Cabello, F., Ortiz, J. M. (2003): Characterization of the Spanish diversity grapevine cultivars using sequence-tagged microsatellite site markers. - Genome 46: $1-9$.

[26] Martinez, L. E., Cavagnaro, P. F., Masuelli, R. W., Zuniga, M. (2006): SSR-based assessment of genetic diversity in Sout American Vitis vinifera varieties. - Plant Science 170: 1036-1044.

[27] Meredith, C., Dangl, G. S., Bowers, J. E. (1996): Clarifying the identitiy of some California winegrapes by DNA profilling. - Riv. Vitic. Enol. 49(1): 65-68.

[28] Meredith, C. (2001): Grapevine genetics: probing the past and facing the future. Agriculturae Conspectus Sientificus 66: 21-25.

[29] Minch, E., Ruiz-Linares, A., Goldstein, D. B., Feldman, M., Cavalli-Sforza, L. L. (1995): Microsat (version 1.4d): a computer program for calculating various statistics on microsatellite allele data. - Stanford. California, University of Stanford.

[30] Nuñez, Y., Fresno, J., Torres, V., Ponz, F., Gallego, F. J. (2004): Practical use of microsatellite markers to manage Vitis vinifera germplasm: Molecular identification of grapevine samples collected blindly in D.O. "El Bierzo" (Spain). - Journal of Horticultural Science \& Biotechnology 79(3): 437-440.

[31] Ocete, R., Arroya-Garcia, R., Morales, M. L., Cantos, M., Gallardo, A., Perez, M. A., Gomez, I., Lopez, M. A. (2011): Characterization of Vitis vinifera L. subspecies sylvestris (Gmelin) Hegi in the Ebro river Basin (Spain). - Vitis 50(1): 11-16.

[32] Riaz, S., Garrison, K. E., Dangl, G. S. (2002): Genetic divergence and chimerism within ancient asexually propagated winegrape cultivars. - Journal of the American Society for Horticultural Science 127(4): 508-514.

[33] Riaz, S., Dangl, G. S., Edwards, K. J., Meredith, C. P. (2004): A microsatellite marker based framework linkage map of Vitis vinifera L. - Theor. Appl. Genet. 108: 864-872. 
[34] Sefc, K. M., Steinkellner, H., Wagner, H. W., Glössl, J., Regner, F. (1997): Application of microsatellite markers to parentage studies in grapevine. - Vitis 36(4): 179-183.

[35] Sefc, K. M., Steinkellner, H., Glössl, J., Kampfer, S., Regner, F. (1998): Reconstruction of a grapevine pedigree by microsatellite analysis. - Theoretical and Applied Genetics 97(12): $227-231$

[36] Sefc, K. M., Regner, F., Turetschek, E., Glössl, J., Steinkellner, H. (1999): Identification of microsatellite sequences in Vitis riparia and their applicability for genotyping of different Vitis species. - Genome 42: 367-373.

[37] Sefc, K. M., Lopes, M. S., Lefort, F., Botta, R., Roubelakis-Angelakis, K. A., Ibañez, J., Pejic, I., Wegner, H. W., Glössl, J., Steinkellner, H. (2000): Microsatellite variability in grapevine cultivars from different European regions and evaluation of assignment testing to assess the geographic origin of cultivars. - Theor. Appl. Genet. 100: 498-505.

[38] Şelli, F., Bakır, M., İnan, G., Aygün, H., Boz, Y., Yaşasın, A. S., Özer, C., Akman, B., Söylemezoğlu, G., Kazan, K., Ergül, A. (2007): Simple sequence repeat-based assessment of genetic diversity in Dimrit and Gemre grapevine accessions from Turkey. - Vitis 46(4): 182-187.

[39] This, P., Jung, A., Boccacci, P., Borrego, J., Botta, R., Constantini, L., Crespan, M., Dangl, G. S., Eisenheld, C., Ferreria-Montteiro, F., Grando, S., Ibáñez, J., Lacombe, T., Laucou, V., Magalhães, R., Meredith, C. P., Milani, N., Peterlunger, E., Regner, F., Zulini, L., Maul, E. (2004): Development of a standard set of microsatellite reference alleles for identification of grape cultivars. - Theor. Appl. Genet. 109: 1448-1458.

[40] Thomas, M. R., Scott, N. S. (1993): Microsatellite repeats in grapevine reveal DNA polymorphisms when analyzed as sequence-tagged sites (STSs). - Theoretical and Applied Genetics.

[41] Van Heerden, C. J., Burger, P., Prins, R. (2018): Microsatellite-based DNA fingerprinting of selected grapevine cultivars. - S. Afr. J. Enol. Vitic. 39(1): 58-66.

[42] Vouillamoz, J. F., McGovern, P., Ergül, A., Soylemezoglu, G., Tevzadze, G., Meredith, C. P., Grando, M. S. (2006): Genetic characterization and relationships of traditional grape cultivars from Transcaucasia and Anatolia. - Plant Genetic Resources 4(2): 144-158.

[43] Wagner, H. W., Sefc, K. M. (1999): IDENTITY 1.0. Centre for Applied Genetics. University of Agricultural Science, Vienna.

[44] Zequim Maia, S. H., Aparecida de Oliveira-Collet, S., Mangolin, C. A., Maria de Fátima, P. S. M. (2018): Differential genetic stability in vineyards of the cultivar 'Italy' (Vitis vinifera L.) cultivated in different regions of Southern and Southwestern Brazil. - Ciência Téc. Vitiv. 33(1): 66-77.

[45] Zullini, L., Fabro, E., Peterlunger, E. (2005): Characterisation of the grapevine cultivar Picolit by means of morphological descriptors and molecular markers. - Vitis 44(1): 3538. 